\title{
Germination and crop yield in cotton - maize cropping system influenced by tillage and land configuration
}

\author{
P. PUVILA*, K. SIDDESWARAN AND P.M. SHANMUGAM \\ Department of Agronomy, Tamil Nadu Agricultural University, COIMBATORE (T.N.) INDIA \\ (Email : earthpuvi@gmail.com)
}

\begin{abstract}
A field experiment with different tillage practices and planting management in cotton - maize cropping systems was conducted under irrigated conditions in a sandy clay loam soil at the Tamil Nadu Agricultural University, Coimbatore during 201112 and 2012-13. Totally there were 8 treatments which were replicated thrice in a Randomized Block Design. The treatments consisted of three tillage practices viz., conventional tillage, reduced tillage and zero tillage and three types of land configurations viz., flat bed and furrow irrigated raised bed (FIRB) which were compared with the existing practice of ridges and furrows. The two years average of the germination and yields of cotton - maize cropping systems as a whole under different tillage and planting management revealed that the zero tillage with flat surface planting system gave lesser number germination percentage and yield compared with other types of tillage and planting management which was followed by reduced tillage once to cotton alone and planting on FIRB and conventional tillage once to cotton alone and planting on FIRB. Tilled plot got more germination percentage compared to no-tilled plots and more yield was registered with tillage once to cotton alone and planting on FIRB and conventional tillage once to cotton alone and planting on FIRB.
\end{abstract}

Key Words : FIRB, Conventional tillage (CT), Reduced tillage (RT), Zero tillage (ZT), Germination

View Point Article : Puvila, P., Siddeswaran, K. and Shanmugam, P.M. (2016). Germination and crop yield in cotton - maize cropping system influenced by tillage and land configuration. Internat. J. agric. Sci., 12 (2) : 252-256, DOI:10.15740/HAS/IJAS/12.2/252-256.

Article History : Received : 01.02.2016; Revised : 04.03.2016; Accepted : 25.04.2016

\footnotetext{
* Author for correspondence
} 